\title{
RESEARCH PAPER \\ ANTIBACTERIAL EFFECT OF OCIMUM GRATISSIMUM AGAINST BACTERIA FROM PAEDIATRIC DIARRHOEAL STOOL SAMPLES IN THE TROPICS
}

\author{
M. B. Odebisi-Omokanye, *T. O. Agbabiaka, R. F. Zakariyah and O. Sanya \\ Department of Microbiology, Faculty of Life Sciences, University of Ilorin, \\ P.M.B. 1515, Ilorin, Nigeria \\ *Corresponding author: agbabiaka.toyin.toyin@gmail.com
}

\begin{abstract}
The upsurge in the prevalence of side effects of many synthetic antimicrobial agents and incidence of multidrug resistant bacteria has spurred scientists on the research for plant based antimicrobial of therapeutic potentials. Ocimum gratissimum presents such potential of high medicinal value. This plant is used in Nigeria traditionally as condiments and for the treatment of various ailments such as pyorrhea, dysentery and bronchitis. Aqueous and ethanolic leaf extracts of $O$. gratissimum was screened for antibacterial activity against bacteria recovered from paediatric diarrhoea stool samples. Both extracts were found to exhibit selective inhibition against the isolates. The diameter zones of inhibition exhibited by the extracts were between $2.50 \pm 0.50 \mathrm{~mm}-26.00 \pm 1.00 \mathrm{~mm}$. The ethanolic and aqueous extracts had minimum inhibitory concentrations that ranged between 15 and $25 \mathrm{mg} / \mathrm{ml}$, the extracts were bacteriostatic. Ethanolic extract showed more inhibitory effects compared to the aqueous extracts. The phytochemical analysis of both extracts revealed the presence of saponins, alkaloids, flavonoids, phenolics, tannins and glycosides, volatile oils, proteins and amino acids and terpernoids. In view of the efficacy of these extracts in inhibiting the growth of diarrhoea-causing organisms in paediatric stool samples, the utilization of the extracts in the formulation of new antibacterial drugs for the treatment of gastroenteritis caused by these organisms is strongly recommended especially when the availability and low cost of this medicinal plant are put into strong consideration.
\end{abstract}

Keywords: Ocimum, diarrhoea, paediatric, stool, antibacterial

\section{INTRODUCTION}

There are about two billion cases of diarrhoeal disease worldwide every year, and 1.9 million children younger than 5 years of age perish from diarrhoea each year, mostly in developing countries. This amounts to $18 \%$ of all the deaths of children under the age of five and means that more than 5000 children are dying every day as a result of diarrhoeal diseases. Of all child deaths from diarrhoea, $78 \%$ occur in the African and South-East Asian regions (WHO, 2014). 
Diarrhoea is the condition of having at least three loose or liquid bowel movements each day which often lasts for a few days and can result in dehydration due to fluid loss. Signs of dehydration often begins with loss of the normal stretchiness of the skin and changes in personality. This can progress to decreased urination, loss of skin color, a fast heart rate, and a decrease in responsiveness as it becomes more severe (WHO, 2014).

Each child under 5 years of age experiences an average of three annual episodes of acute diarrhoea. Globally in this age group, acute diarrhoea is the second leading cause of death (after pneumonia), and both the incidence and the risk of mortality from diarrhoeal diseases are greatest among children in this age group, particularly during infancy - thereafter, rates decline incrementally (WHO, 2010).

In developing countries, enteric bacteria and parasites causing diarrhoea are more prevalent than viruses and typically peak during the summer months. The bacteria species involved include: Campylobacter species, Salmonella species, Shigella species, E. coli VTEC, Enteroaggregative E. coli (EAEC), Enteroinvasive $E$. coli (EIEC), Enteropathogenic E. coli (EPEC) and Vibrio species. Several other bacteria species have been found out to cause diarrhoea (Kent and Banks, 2009).

Ocimum gratissimum (Lamiaceae), commonly known as "alfavaca" is naturally used in the treatment of diarrhoea, headache, fever, ophthalmic, skin disease and pneumonia. The Ocimum oil is also active against several species of bacteria, Staphylococcus aureus, Listeria monocytogenes, Escherichia coli, Shigella, Salmonella and Proteus (Janine et al., 2005). In Nigeria, it is found in the Savannah and coastal areas, the plant is called "effinrinnla" by the Yoruba speaking tribe, "Ahuji" by the Igbos, and the Hausas call it Daidoya" (Effraim et al., 2003). The flowers and the leaves of this plant are rich in essential oils so it is used in preparation of teas and infusion
(Rabelo et al., 2003).

The tribes of Nigeria use the leaf extract in treatment of diarrhoea, while the cold leaf infusions are used for the relief of stomach upset and haemorrhoids (Kabir et al., 2005). Various species of Ocimum gratissimum, for example O. viride Linn, O. suave Linn, O. basilicum Linn and O. canum Sims have been reported for their numerous medical uses (Mshana et al., 2000). Studies have proved Ocimum gratissimum to be a useful medication for diarrhoea in people living with Human Immuno deficiency Virus (HIV), and Acquired Immuno Deficiency Syndrome virus AIDs (Elujoba, 2000).

Several species and varieties of plants of the genus Ocimum have been reported to yield oil of diverse nature, commonly known as basilic oils. Janine et al., (2005) reported some chemical compounds and active ingredients found in these plants such as; eugenol, linaol, methyl cinnamate, camphor and thymol. It has been demonstrated that the eugenol isolated from Ocimum gratissimum presented antimicrobial, antihelminthic, nematicidal activities or fungistatic properties (Pessoa et al., 2005). The objectives of this study were to ascertain the activity of aqueous and ethanolic leaf extracts of Ocimum gratissimum against bacteria isolated from paediatric diarrhoeal stool samples; determine the minimum concentration of the extracts required to inhibit the growth of the isolates by both plate and broth method (MIC); determine the minimum concentration of the extracts required to kill the isolates (MBC) and compare the activity of the plant extracts to that of standard antibiotics.

\section{MATERIALS AND METHODS}

\section{Bacterial cultures}

A total of 36 samples from patients suffering from diarrhoea were collected from the "Center Igboro Pediatric Hospital”, Ilorin, Kwara State, Nigeria. Culture media which included Eosin Methylene Blue Agar and Salmonella Shigella Agar and MacConkey Agar were used for the 
isolation of the organisms.

\section{Plant identification}

Fresh leaves of Ocimum gratissimum were collected from Ilorin, Kwara State of Nigeria. They were authenticated and identified at the herbarium of the University of Ilorin, Ilorin, Kwara State, Nigeria and given voucher number: UIH001/984.

\section{Ethical issue}

Ethical approval was given for this study by Department of Microbiology, University of Ilorin, Ilorin, Nigeria.

Preparation and extraction of crude extracts The leaves of Ocimum gratissimum were screened manually. The materials were cleaned with sterile distilled water; air dried and pounded. Five hundred grams of the pounded Ocimum gratissimum leaves were soaked in $70 \%$ ethanol for $72 \mathrm{hrs}$. The extracts were filtered and ethanol extracts were evaporated using a rotary evaporator at $40^{\circ} \mathrm{C}$ and concentrated further using a water bath at temperature $50^{\circ} \mathrm{C}$. The residues obtained were dissolved in $1 \%$ dimethyl sulphoxide (DMSO). The weight of the extract was determined and stored below ambient temperature (Mbata and Saikia, 2012). The same procedure was used for the aqueous extraction using sterile distilled water as the solvent and $1000 \mathrm{ml}$ of water was used to soak $90 \mathrm{~g}$ of Ocimum gratissimum leaf.

\section{Analysis of phytochemicals in the plant ex- tracts}

The photochemical screening was carried out using the standard procedures of analysis as described by Trease and Evans (2002).

\section{Saponins}

$5 \mathrm{ml}$ of distilled water was added to $0.5 \mathrm{~g}$ of the plant extract in a test tube. The solution was shaken vigorously and observed for a stable persistent froth or foam at the top. It was then allowed to stand for about 10 minutes; persistence of the foam after $10 \mathrm{mins}$ shows positive result.
Tannins

About $0.5 \mathrm{~g}$ of the plant extract was boiled in $10 \mathrm{ml}$ of water in a test tube and then filtered. A few drop of $0.1 \%$ ferric chloride was added and observed for brownish green or blue or blue green coloration.

\section{Alkaloids}

The test for alkaloids included diluting $0.5 \mathrm{~g}$ of the plant extract with $10 \mathrm{ml}$ of acid alcohol, boiling and filtering it. $2 \mathrm{ml}$ of dilute ammonia was added to $5 \mathrm{ml}$ of the filtrate; $5 \mathrm{ml}$ of chloroform was added and shaken gently to extract the alkaloid base. The chloroform layer was extracted with $10 \mathrm{ml}$ of acetic acid. This was divided into two portions. Meyer's reagent was added to one portion and Dragendorff's regent to the other. The formation of a cream (with Meyer's reagent) or reddish brown precipitate (Dragendorff's reagent) was regarded as positive for the presence of alkaloids.

\section{Flavonoids}

About $5 \mathrm{ml}$ dilute ammonia was added to a portion of the plant extract, followed by addition of $1 \mathrm{ml}$ of concentrated sulphuric acid. A yellow coloration that disappears on staining indicated the presence of flavonoid.

\section{Carbohydrates}

Sulphuric acid was added to $1 \mathrm{ml}$ of the plant extract in a test tube. The mixture was heated in a water bath for 15 minutes and Fehling solution added to the mixture. A brick red precipitate indicating the presence of carbohydrate was formed

\section{Terpenoids}

$2 \mathrm{ml}$ of chloroform was added to $0.5 \mathrm{~g}$ of the extract. Concentrated sulphuric acid $(3 \mathrm{ml})$ was carefully added to form a layer. A reddish brown coloration of the interface was formed indicating the presence of terpenoids.

\section{Phytosterols}

Extracts were treated with chloroform and filtered. The filtrates were treated with few drops of acetic anhydride, boiled and cooled. Concentrated sulphuric acid was added. Formation of 
brown ring at the junction indicated the presence of phytosterols.

\section{Phenols}

Extracts were treated with 3 to 4 drops of ferric chloride solution. Formation of bluish black colour indicated the presence of phenols.

\section{Protein and amino acid}

The extracts were treated with few drops of concentrated nitric acid. Formation of yellow colour indicated the presence of proteins.

\section{Glycoside}

Extracts were treated with ferric chloride solution and immersed in boiling water for about 5 minutes. The mixture was cooled and extracted with equal volumes of benzene. The benzene layer was separated and treated with ammonia solution. Formation of rose pink colour in the ammonical layer indicated the presence of anthranol glycoside.

\section{Volatile oil}

Extracts were treated with $0.1 \mathrm{ml}$ dilute sodium hydroxide and dilute hydrochloric acid. Formation of white precipitate indicated the presence of volatile oil.

\section{Antibacterial sensitivity test}

A stock preparation of the extract was got by dissolving $2 \mathrm{~g}$ of crude extract in $5 \mathrm{ml}$ of dimethylsulphoxide (DMSO) at concentration of $400 \mathrm{mg} / \mathrm{ml}$. Concentration of 300,200 and $100 \mathrm{mg} / \mathrm{ml}$ were then prepared from the stock $(400 \mathrm{mg} / \mathrm{ml})$ concentration (Akujobi et al., 2004).

The antibacterial tests of the plant extracts were done on the test isolate using the agar-gel diffusion inhibition test as described by Opara and Anasa (1993). The organisms were inoculated into $9 \mathrm{ml}$ nutrient broth and incubated till turbidity was noticed. It was then asceptically introduced and evenly spread on the surface of gelled sterile Mueller-Hinton agar plates using a sterile swab stick. Four wells of about $6.0 \mathrm{~mm}$ diameter were asceptically punched on each agar plate using a sterile cork borer, allowing at least $30 \mathrm{~mm}$ between adjacent wells and between peripheral wells and the edge of the petri dish. Fixed volumes of the extract were then introduced into the wells in the plates. A control well was in the center with the extracting solvent. The plates were allowed on the bench for 40 minutes for pre-diffusion of the extract to occur and then incubated at $37^{\circ} \mathrm{C}$ for 24 hours. The resulting zones of inhibition were measured using a ruler calibrated in millimeters (Pessoa et al., 2005). Assays were performed in triplicate and the data are shown as the mean \pm standard deviation (SD).

\section{Determination of minimum inhibitory con- centration (MIC)}

The MIC of the potent extract was determined using the agar plate technique. Lower concentrations such as: 90, 70, 50, 45, 40. 30, 25, 20, 15 and $10 \mathrm{mg} / \mathrm{ml}$ were used following the normal testing procedure. The MICs were read as the least concentration that inhibited the growth of the test organisms. The same procedure was followed for determining the MIC for the aqueous extract.

\section{Determination of MIC using McFarland's standard}

Nutrients broths were prepared and autoclaved then dispensed into test tubes accordingly. The broths were prepared for the treatment, control for organism and controls for extract. The treatment test tubes contained $9.7 \mathrm{ml}$ of sterile nutrient broth, $0.2 \mathrm{ml}$ of the extract, $0.1 \mathrm{ml}$ of the organism and it was incubated at $37^{\circ} \mathrm{C}$ for $18 \mathrm{hrs}$. The organism control test tubes $(9.9 \mathrm{ml}$ sterile nutrient broth and $0.1 \mathrm{ml}$ organism) were also incubated at $37^{\circ} \mathrm{C}$ for $18 \mathrm{hrs}$. The incubated organism was standardized with the McFarlands solution and used for the inoculation. The extract control test tubes contained $9.8 \mathrm{ml}$ of sterile nutrient broth and $0.2 \mathrm{ml}$ of extract. The turbidity of the different preparations was then checked with a spectrophotometer and the result analyzed. 
Minimum bactericidal concentration (MBC)

The MBCs were determined by selecting the least concentration that inhibited the growth of the test organisms. The organism was inoculated into the concentration preparation and incubated at $37^{\circ} \mathrm{C}$ for $18 \mathrm{hrs}$ and $0.1 \mathrm{ml}$ from it was inoculated into nutrient agar using pour plate method. The plate was then incubated for further 24 hours at $37^{\circ} \mathrm{C}$. Absence of microbial growth at this concentration was taken as the MBC.

\section{Standard antibiotics sensitivity test}

Mueller Hilton agar was prepared according to the manufacturer's instruction, autoclaved and poured into Petridishes. It was allowed to solidify and the test organisms were spread on the medium using a sterile swab stick. The antibiotic disc was then placed on it and incubated at $37^{\circ} \mathrm{C}$ for 18 hours. Zones of inhibition after incubation were measured in millimeters. The interpretations of the measurements as sensitive, intermediate and resistant were made according to the manufacturer's standard zone size interpretative manual. The intermediate readings were considered as sensitive for the assessment of the data.

\section{RESULTS}

Table 1 shows the phytochemicals of the leaf extracts of Ocimum gratissimum. Result shows the presence of carbohydrates, saponins, phenol, flavonoids proteins, volatile oil, terpernoids and tannins in both aqueous and ethanolic extract while alkaloids was only present in the aqueous extract. Volatile oil and glycosides were present in the ethanolic extract but absent in the aqueous extract.

Table 2 shows the antimicrobial activity of ethanolic leaf extract with the highest diameter zone of inhibition against Salmonella enterica $(26.00 \pm 1.00 \mathrm{~mm})$ and the lowest against Shigella sonnei $(10.00 \pm 1.00 \mathrm{~mm})$ and for the aqueous leaf extract, Klebsiella pneumoniae showed the highest susceptibility with diameter zone of inhibition of $19.00 \pm 1.00 \mathrm{~mm}$ while Bacillus cereus showed the lowest susceptibility with diameter zone of inhibition of $2.50 \pm 0.50 \mathrm{~mm}$.

Each value is the mean \pm standard deviation of the zones of inhibition in triplicate $(n=3)$ readings. The letters $\mathrm{a}, \mathrm{b} \mathrm{c}$ and $\mathrm{d}$ represent ranking of the means across each group of isolate. Values not sharing the same superscript differ

Table 1: Phytochemicals detected in the aqueous and ethanolic leaf extracts of Ocimum gratissimum

\begin{tabular}{llcc}
\hline S/No. & Phytochemicals & Aqueous & Ethanolic \\
\hline 1. & Saponins & + & + \\
2. & Alkaloids & + & - \\
3. & Carbohydrates & - & + \\
4. & Phytosterols & - & - \\
5. & Phenol & + & + \\
6. & Flavonoids & + & + \\
7. & Glycosides & - & - \\
8. & Volatile oil & - & + \\
9. & Terpernoids & + & + \\
10. & Tannins & + &
\end{tabular}


69 Agbabiaka et al.

Table 2: Antimicrobial activities of aqueous and ethanolic leaf extracts of Ocimum gratissimum at different concentrations on bacterial isolates

\begin{tabular}{lllllll}
\hline & & SAL & SHI & ESC & KLE & BAC \\
\hline \multirow{4}{*}{ Aqueous } & 400 & $18.00 \pm 1.00^{\mathrm{d}}$ & $16.50 \pm 0.50^{\mathrm{d}}$ & $17.00 \pm 1.00^{\mathrm{d}}$ & $19.00 \pm 1.00^{\mathrm{c}}$ & $8.50 \pm 0.50^{\mathrm{d}}$ \\
& 300 & $14.00 \pm 1.00^{\mathrm{c}}$ & $14.50 \pm 0.50^{\mathrm{c}}$ & $14.00 \pm 1.00^{\mathrm{c}}$ & $17.00 \pm 1.00^{\mathrm{b}}$ & $5.50 \pm 0.50^{\mathrm{c}}$ \\
& 200 & $13.50 \pm 0.50^{\mathrm{b}}$ & $11.50 \pm 0.50^{\mathrm{a}}$ & $11.50 \pm 0.50^{\mathrm{a}}$ & $17.00 \pm 1.00^{\mathrm{b}}$ & $3.00 \pm 1.00^{\mathrm{b}}$ \\
& 100 & $12.00 \pm 1.00^{\mathrm{a}}$ & $12.00 \pm 1.00^{\mathrm{b}}$ & $11.00 \pm 1.00^{\mathrm{b}}$ & $16.50 \pm 0.50^{\mathrm{a}}$ & $2.50 \pm 0.50^{\mathrm{a}}$ \\
& & & & & \\
Ethanolic & 300 & $26.00 \pm 1.00^{\mathrm{d}}$ & $11.00 \pm 1.00^{\mathrm{d}}$ & $18.50 \pm 0.50^{\mathrm{d}}$ & $16.50 \pm 0.50^{\mathrm{d}}$ & $19.00 \pm 1.00^{\mathrm{c}}$ \\
& 200 & $23.83 \pm 0.76^{\mathrm{c}}$ & $10.50 \pm 0.50^{\mathrm{a}}$ & $15.50 \pm 0.50^{\mathrm{c}}$ & $16.00 \pm 1.00^{\mathrm{b}}$ & $17.00 \pm 1.00^{\mathrm{b}}$ \\
& 100 & $14.00 \pm 1.00^{\mathrm{a}}$ & $10.00 \pm 1.00^{\mathrm{b}}$ & $10.50 \pm 0.50^{\mathrm{a}}$ & $12.50 \pm 0.50^{\mathrm{a}}$ & $15.00 \pm 1.00^{\mathrm{a}}$ \\
\hline
\end{tabular}

KEY: $S A L=$ Salmonella enterica; $S H I=S h i g e l l a$ sonnei.; $E S C=$ Escherichia coli; $K L E=K l e b s i e l l a ~ p n e u m o n i a e$; $B A C=$ Bacillus cereus

Table 3: Minimum inhibitory concentration of the aqueous leaf extract of Ocimum gratissimum

\begin{tabular}{lcc}
\hline Test organisms & $\begin{array}{c}\text { Minimum inhibitory concentrations (MIC) } \mathbf{~ m g / m l} \\
\text { Aqueous }\end{array}$ & Ethanolic \\
\hline Salmonella enterica & 25 & 15 \\
Shigella sonnei & 25 & 15 \\
Escherichia coli & 25 & 25 \\
Klebsiella pneumoniae & 25 & 15 \\
Bacillus cereus & 25 & 20 \\
\hline
\end{tabular}

significantly at $p<0.05$.

Table 3 shows the minimum inhibitory concentration (MIC) of the aqueous and extracts on the five bacterial isolates as $25 \mathrm{mg} / \mathrm{ml}$. The MIC for $S$. enterica and $S$. sonnei is $15 \mathrm{mg} / \mathrm{ml}$, that of E. coli is $25 \mathrm{mg} / \mathrm{ml}$ while that of $K$. pneumoniae and $B$. cereus is $15 \mathrm{mg} / \mathrm{ml}$ and $20 \mathrm{mg} / \mathrm{ml}$ respectively.

Table 4 shows that both the aqueous and ethanolic extract had no bactericidal activity against the bacterial isolates.

Table 5 shows the antimicrobial susceptibility to standard antibiotics. The antibiotics show higher antimicrobial activity than that of the leaf extract even at lower concentrations. Salmonella enterica has the highest susceptibility to ciprofloxacin at concentration five.

\section{DISCUSSION}

Several authors have described diarrhoea infections as the most common cause of morbidity 
Effect of Ocimum gratissimum on bacteria from paediatric diarrhoeal stool ... 70

Table 4: Minimum bactericidal concentration of the aqueous and ethanolic leaf extracts of Ocimum gratissimum against the bacterial isolates

\begin{tabular}{lcc}
\hline Isolates & Minimum Bacterial Concentration (MBC), mg/ml. \\
\hline & Aqueous extracts & Ethanolic extract \\
Salmonella enterica & - & - \\
Shigella sonnei & - & - \\
Escherichia coli & - & - \\
Klebsiella pneumoniae & - & - \\
Bacillus cereus & - & - \\
\hline
\end{tabular}

KEY: No bactericidal activity

Table 5: Antibacterial susceptibility of the bacterial isolates to standard antibiotics

\begin{tabular}{|c|c|c|c|c|c|}
\hline \multirow[t]{2}{*}{ Antibiotics used } & \multicolumn{5}{|c|}{ Mean values of zone of inhibition (mm) } \\
\hline & S. enterica & S. sonnei & E.coli & K. pneumoniae & B. cereus \\
\hline CIP & $28 \quad[\mathrm{~S}]$ & $20 \quad[S]$ & $20 \quad[S]$ & $21.5[\mathrm{~S}]$ & $20 \quad[S]$ \\
\hline LEV & $25.5 \quad[S]$ & $19.5[\mathrm{~S}]$ & $20 \quad[S]$ & $20.5[S]$ & $24 \quad[S]$ \\
\hline GEN & $16.5[\mathrm{~S}]$ & $15 \quad[S]$ & $17 \quad[\mathrm{~S}]$ & $20 \quad[S]$ & $15.5[\mathrm{~S}]$ \\
\hline AMK & {$[\mathrm{S}]$} & $20.5[S]$ & $20 \quad[S]$ & $20 \quad[S]$ & $\begin{array}{ll}0 & {[\mathrm{R}]}\end{array}$ \\
\hline MEM & {$[\mathrm{R}]$} & $\begin{array}{ll}0 & {[\mathrm{R}]}\end{array}$ & $20 \quad[S]$ & $\begin{array}{ll}0 & {[\mathrm{R}]}\end{array}$ & $0 \quad[R]$ \\
\hline CTX & {$[\mathrm{R}]$} & {$[\mathrm{R}]$} & $\begin{array}{ll}0 & {[\mathrm{R}]}\end{array}$ & $23 \quad[S]$ & $0 \quad[\mathrm{R}]$ \\
\hline AMX & {$[\mathrm{R}]$} & {$[\mathrm{R}]$} & $\begin{array}{ll}0 & {[\mathrm{R}]}\end{array}$ & {$[\mathrm{R}]$} & $\begin{array}{ll}0 & {[\mathrm{R}]}\end{array}$ \\
\hline TET & 17 & {$[\mathrm{R}]$} & $20 \quad[S]$ & {$[\mathrm{R}]$} & $0 \quad[\mathrm{R}]$ \\
\hline COT & {$[\mathrm{R}]$} & {$[\mathrm{R}]$} & $\begin{array}{ll}0 & {[\mathrm{R}]}\end{array}$ & {$[\mathrm{R}]$} & $\begin{array}{ll}0 & {[\mathrm{R}]}\end{array}$ \\
\hline CRX & {$[\mathrm{R}]$} & {$[\mathrm{R}]$} & {$[\mathrm{R}]$} & {$[\mathrm{R}]$} & $13.5[\mathrm{R}]$ \\
\hline $\mathbf{C N}$ & {$[\mathrm{R}]$} & {$[\mathrm{R}]$} & {$[\mathrm{R}]$} & [R] & $13.5[\mathrm{R}]$ \\
\hline CTR & 15 & $19[\mathrm{I}]$ & $17.5[\mathrm{I}]$ & $20.5[\mathrm{I}]$ & $0 \quad[\mathrm{R}]$ \\
\hline VAN & {$[\mathrm{R}]$} & $\begin{array}{ll}0 & {[\mathrm{R}]}\end{array}$ & $16.5[\mathrm{~S}]$ & {$[\mathrm{R}]$} & $19 \quad[\mathrm{~S}]$ \\
\hline AUG & {$[\mathrm{R}]$} & {$[\mathrm{R}]$} & $\begin{array}{ll}0 & {[\mathrm{R}]}\end{array}$ & {$[\mathrm{R}]$} & $0 \quad[\mathrm{R}]$ \\
\hline ERY & {$[\mathrm{R}]$} & $\begin{array}{ll}0 & {[\mathrm{R}]}\end{array}$ & {$[\mathrm{R}]$} & {$[\mathrm{R}]$} & $\begin{array}{ll}0 & {[\mathrm{R}]}\end{array}$ \\
\hline AMP & {$[\mathrm{R}]$} & $\begin{array}{ll}0 & {[\mathrm{R}]}\end{array}$ & {$[\mathrm{R}]$} & {$[\mathrm{R}]$} & 13 [R] \\
\hline
\end{tabular}

KEY: CIP Ciprofloxacin, LEV Levofloxacin, GEN Gentamicin, AMK Amikacin, MEM Meropenem, CTX Cefotaxime, AMX Amoxicillin TET Tetracyclin, COT Cotrimoxazole, CRX Cifuroxime, CN Cephalexin, CTR Ceftriaxone, VAN Vancomicin, AUG Augmentin, ERY Erythromycin, AMP Ampicillin, S-Susceptible, I- Intermediate, R-Resistant

and mortality in children worldwide (Bente et al., 2005; WHO, 2005). Five bacteria isolated from the samples included Salmonella enterica, Shigella sonnei, Escherichia coli, Klebsiella pneumoniae and Bacillus cereus, and these were similar to what was obtained by Ani et al.
(2003) from stool samples of children. The high occurrence of these organisms could be attributed to poor sanitation on the part of the parents or wards of such infants.

As shown in Table 1, the antibacterial activities 


\section{Agbabiaka et al.}

of the aqueous and ethanolic extracts of this plant could be attributed to the presence of the active ingredients and secondary metabolites. The mechanism of action by which the phytochemical constituents of Ocimum gratissimum exert its antibacterial activity might be attributed to bacterial enzyme inhibition (Janine et al., 2005).

Surh (2003) opined that phytochemicals may act by inhibiting microbial growth, inducing cellular membrane perturbations, interference with certain microbial metabolic processes, modulation of signal transduction or gene expression pathways.

Saponins obtained from the plant extract were also obtained by Moyo et al. (2012) which is believed to act by altering the permeability of cell walls and hence exert toxicity on all organized tissues. Saponins exert some antibacterial activity by combining with cell membranes to elicit changes in cell morphology leading to celllysis.

The result of this study as stated in Table 2 showed that aqueous and ethanolic extracts Ocimum gratissimum showed varying degrees of inhibitory effects on the growth of the five organisms but the highest inhibition was at $400 \mathrm{mg} / \mathrm{ml}$ and the lowest was at $100 \mathrm{mg} / \mathrm{ml}$.

The result of the preliminary phytochemical screening revealed the presence of tannins, phenolic compounds, terpenoids, sterols, saponins and alkaloids in $O$. gratissimum. Ali et al. (2001) also obtained alkaloids, flavonoids, saponins, sterols and tannins and opined that the associated activity might be correlated to the presence of the individual fraction. The antimicrobial activity of flavonoids may be due to their ability to complex with extracellular and soluble protein and to complex with bacterial cell wall; thereby disrupting their membrane integrity (Tsuchiya et al., 1996). It is noteworthy that phytochemicals are the most important antioxidants in dietary.
Tannins have been reported to hinder the development of micro-organisms by their ability to precipitate and inactivate microbial adhesions enzymes and cell envelope proteins. The significant activity observed in this study could thus be attributed to the interaction of one or more of the identified metabolites against the bacterial isolates.

The ethanolic and aqueous extracts exhibited broad-spectrum antibacterial activity against the isolates at concentrations of $400 \mathrm{mg} / \mathrm{ml}$ and below are considered as promising bioactive agents (Mitscher et al., 1999). Falodun et al (2006) reported that polar solvents like ethanol diffuse faster into the solid plant tissues and solubilize compounds faster than water, which is a non- polar solvent. This justifies the results in Table 2 that showed that the ethanolic extract has the higher zone of inhibition at $400 \mathrm{mg} / \mathrm{ml}$ compared to that of the aqueous extracts.

The result in Table 2 concluded that the ethanolic leaf extract showed broader and greater spectra of activity against the tested organisms than the aqueous leaf extracts. The results obtained also showed that the activity of all the extracts were concentration dependent as the zone of inhibition decreases with decreasing concentrations and similar results have been reported by several researchers (El-Mahmood et al., 2008).

Demonstration of low MIC values is an indication that the phytoconstituents of the plant have high therapeutic properties and therefore justifies its common usage in traditional medicinal uses though the therapeutic properties may even be more greatly increased if used in a refined form. The aqueous extract has a uniform MIC value of $25 \mathrm{mg} / \mathrm{ml}$ for all the five bacterial isolates (Table 3) but the MIC for the ethanolic extract differs for some of the bacterial isolates, Salmonella enterica, Shigella sonnei and Klesiella pneumoniae have percentage MIC values of $15 \mathrm{mg} / \mathrm{ml}$ while Escherichia coli had $25 \mathrm{mg} /$ $\mathrm{ml}$ and Bacillus cereus had $20 \mathrm{mg} / \mathrm{ml}$. However when both extract were tested for MBC they 
Effect of Ocimum gratissimum on bacteria from paediatric diarrhoeal stool... 72

were bacteriostatic and this may be due to contamination of the leaf extracts or the evaporation of some essential oils during concentration as heat was applied to aid easier evaporation of the extracting solvent.

All the five bacterial isolates were tested against standard antibiotics like Ciprofloxacin, Levofloxacin, Gentamicin, Amikacin, Meropenem, Cefotaxime, Amoxicillin Tetracycline, Cotrimoxazole, Cefuroxime, Cephalexin, Ceftriaxone, Vancomicin, Augmentin, Erythromycin, and Ampicillin. The result in Table 5 showed that the bacterial isolates showed resistance to most of the standard antibiotics but most of the bacterial isolates were susceptible to Ciprofloxacin, Levofloxacin and Gentamicin. This may be due to the fact that the antibiotics are in pure state and has refined processes that have established it as a standard antibiotic. The result when compared with the diameter zone of inhibition of the aqueous and ethanolic leaf extracts showed that the leaf extracts competed fairly with the standard antibiotics.

This research work established the fact that Ocimum gratissimum leaf extract could be used in the treatment of dysentery or diarrhoea infection in children associated with Escherichia coli, Salmonella enterica, Klebsiella pneumonia, Shigella sonnei and even Bacillus cereus. Recently, there has been an increase in the number of people in Nigeria depending on herbal drugs. Herbal drugs are cheap, rapidly available and unadulterated. Their antibacterial activity could be increased by purification and subsequent concentration of the active ingredients.

The 'Green' movement in Western society has changed attitudes of the general public who now view naturally derived substances and extracts as being inherently safer and more desirable than synthetic chemical products thereby leading to the net increase in sales of herbal preparations. Therefore, $80 \%$ of people in the developing world rely on natural prod- ucts for primary healthcare for man (WHO, 2002).

\section{CONCLUSION}

Aqueous and ethanolic extract of Ocimum gratissimum at different concentrations exhibited antimicrobial activity on bacterial isolated from paediatric diarrhoeal stool, the bacterial isolates included Salmonella enterica, Shigella sonnei, Escherichia coli, Klebsiella pneumoniae and Bacillus cereus. This may be attributed to the presence of phytochemical compounds identified in this study. The lower inhibitory properties may be due to over exposure of the plant extract to heat source, air, sunlight and the unit operations during the production of the paste from the leaves which might have influenced their activity as some of the active ingredients may be volatile in nature. This study indicates clearly that Ocimum gratissimum possesses a valuable but yet to be tapped potential which if exploited will benefit the pharmaceutical industries and the nation as a whole.

However the findings from this study could be of interest and bring about the need for further investigations in terms of toxicological studies and purification of active substances with the plant extract in drug development.

\section{REFERENCES}

Akujobi, C., Anyanwu, B. N., Onyeze, C. and Ibekwe, V. I. (2004). Antibacterial Activities and Preliminary Phytochemical Screening of Four Medical Plants. Journal of Applied Science,7(3): 4328-4338.

Ali, N. A., Julich, W. D., Kusnick, C. and Lindequist, U. (2001). Screening of Yemeni Medicinal Plants for Antibacterial and Cytotoxic Activities. Journal of Ethnopharmacology, 74 (2):173-179.

Ani, A., Takahashi, M., Saida, H., Kozak, W., Kumar, V., Shonekan, R. A. and Agbolahon, B. E. (2003). Aetiological Studies of Infantile Diarrhoea seen in Jos Teaching Hospital, Jos, 


\section{Agbabiaka et al.}

Nigeria: A Preliminary Report 23.

Bente, O., Jacob, N. and Bottiger, B. (2005). Etiology of Diarrhoea in Young Children in Denmark: A Case Study, 43:3636-3641.

Effraim, K. D., Jacks, T. W. and Sodipo, O. A. (2003). Histopathological Studies on the Toxicity of Ocimum Gratissimum Leave Extract on some Organs of Rabbit. African Journal of Biomedical Research, 6: 21-25.

El-Mahmood, A. M, Doughari, J. H. and Ladan N. (2008). Antimicrobial Screening of Stem Bark Extracts of Vitellaria Paradoxa against some Enteric Pathogenic Microorganisms. African Journal of Pharmacy and Pharmacology, 2(5): 089-094.

Elujoba, A. A. (2000). Studies on the Anti Diarrhoea Activity of Ocimum Gratissimum. University of Ile Ife Press.

Falodun, A., Okunrobo, L. O. and Uzoamaka, N. (2006). Phytochemical Screening and Anti-inflammatory Evaluation of Methanolic and Aqueous Extracts of Euphorbia Heterophylla Linn (Euphorbiaceae). African Journal of Biotechnology, 5(6): 529-531.

Janine de Aquino, L., Xisto, S. P., Orionaida de Fatima, L. F., Realino de Paula, J., Pedro, H. F., Hasimoto de Suza, L. K., Aline de Aquino, L. and Maria de Rosario, R. S. (2005). Antifungal Activity from Ocimum Gratissimum L. towards Cryptococus Neoformans. Memórias do Instituto Oswald Cruz. 100(1): 55-58.

Kabir, O. A., Olukayode, O., Chidi, E. O., Christopher, C. I. and Kehinde, A. F. (2005). Screening of crude extracts of six medicinal plants used in South West Nigerian unorthodox medicine antimethicillin resistant Staphylococcus aureus activity. BMC Complementary and Alternative Medicine, 5:1472 -1483 .

Kent, A .J. and Banks, M. R. (2010). Pharma- cological management of diarrhoea. Gastroenterology Clinics of North America, 39(3): 495-507.

Mbata, T. I. and Saikia, A. (2005). Antibacterial Activity of Essential oil from Ocimum gratissimum on Listeria monocytogenes. Internal Journal of Food Safety, 5(7):15-19.

Mitscher, L. A., Leu, R. P., Bathala, M. S., Wu, W. N., Beal, J. L. and White, R. (1999). Antimicrobial Agents from Higher Plants: Introduction, Rationale and Methodology. Llyodia 35: 157-166.

Moyo, B., Masika P. J. and Muchenje, V. (2012). Antimicrobial Activities of Moringa Oleifera Extracts. African Journal of Biotechnology, 12: 34-42.

Mshana, N. R., Abbiw, D. K., Addae-Mensah, I., Adjanohoun, E., Ahji, M. R. A., EnowOrock, E. G., Gbile, Z. O., Odei, M. A., Adenlami, H., Oteng-Yeboah, A. A., Sarppony, K., Sofowora, A. and Tackie, A. N. (2000). Traditional medicine and pharmacopoeia contribution to the revision of Ethnobotanical and floristic studies in Ghana, Scientific, Technical and Research Commission of the Organization of African Unity.

Opara, A. A. and Anasa, M. A. (1993). The antibacterial activity of Tea and Coffee on selected Organisms. Journal of Medical Laboratory Science, 3:45-48.

Pessoa, L. M., Morais, S. M., Bevilaque, C. M. L. and Luciano, J. H. S. (2005). Antihelmintic activity of essential oil of Ocimum gratissimum Linn, and eugenol against Heamonchuscontortus. Veterinary Parasitology, 109: 59-63.

Rabelo, M., Souza, E. P. and Soares, P. M. G. (2003). Antinociceptive Properties of the Essential Oil of Ocimum gratissimum L. (Labiatae) in mice. Brazilian Journal of Medical and Biological Research, 36(4): 521 
$-4$.

Surh, Y. J. (2003). Cancer chemoprevention with dietary phytochemicals. Natural Reviews in Cancer. 3: 768-780.

Trease, G. E. and Evans, W. C. (2002). Trease and Evans Pharmacognosy. 15th edition, W. R. Saunders, London.

Tsuchiya, H. M. S., Iyazaki, T., Fujiwara, S., Taniyaki, S., Ohyama, M., Tanaka, T. and Inuwa, M. (1996). Comparative study on the Antibacterial Activity of Bacterial Flavones against Methicillin Resistant Staphylococcus aureus. Journal of Ethnopharmacology, 50:
27-34.

WHO, (2002). Traditional Medicine: Growing Needs and Potential. WHO Policy Perspectives on Medicines. World Health Organization, Geneva.

WHO, (2005). Reading on Diarrhoea. Student Manual, Geneva.

World Health Organization (2014). Diarrhoeal disease Fact sheet and children recommendations of the Advisory Committee on Immunization practices (ACIP). Mortality and Morbidity Weekly Report. 